\title{
Frontiers of Shame and Repulsion
}

\author{
A.-Chr. Engels-Schwarzpaul
}

\section{Introduction: Sydney 2004, Anaura Bay 1769}

At the 2004 Sydney Biennale a "traditional wooden dunny" (Bond, 2004), ${ }_{1}^{1}$ imported from New Zealand, featured centrally in Daniel Malone's A Long Drop to Nationhood. Set at the end of a long corridor and flanked by a mural inspired by Aboriginal artist Albert Namatjira, it is intentionally reminiscent of a scene in Tracy Moffatt's short film Night Cries, where an adopted Aboriginal daughter wheels her white mother to the outhouse. The outhouse, an "essential common denominator of two closely linked cultures" (Wei, 2004), according to Malone represents the pioneering spirit of the 'colonial adventure' in both Australia and Aotearoa/New Zealand. Engaging "with questions of belonging and place", he also plays on the contrast between the outhouse as "fundamentally associated with waste" and the museum as a place concerned with "high eternal values" (Daniel Malone, 2004). To interrogate such a body/mind split, alongside the cliché of the South as body and emotion, as opposed to to the North as mind and reason, was the concern of the Sydney Biennale On Reason and Emotion. ${ }^{2}$

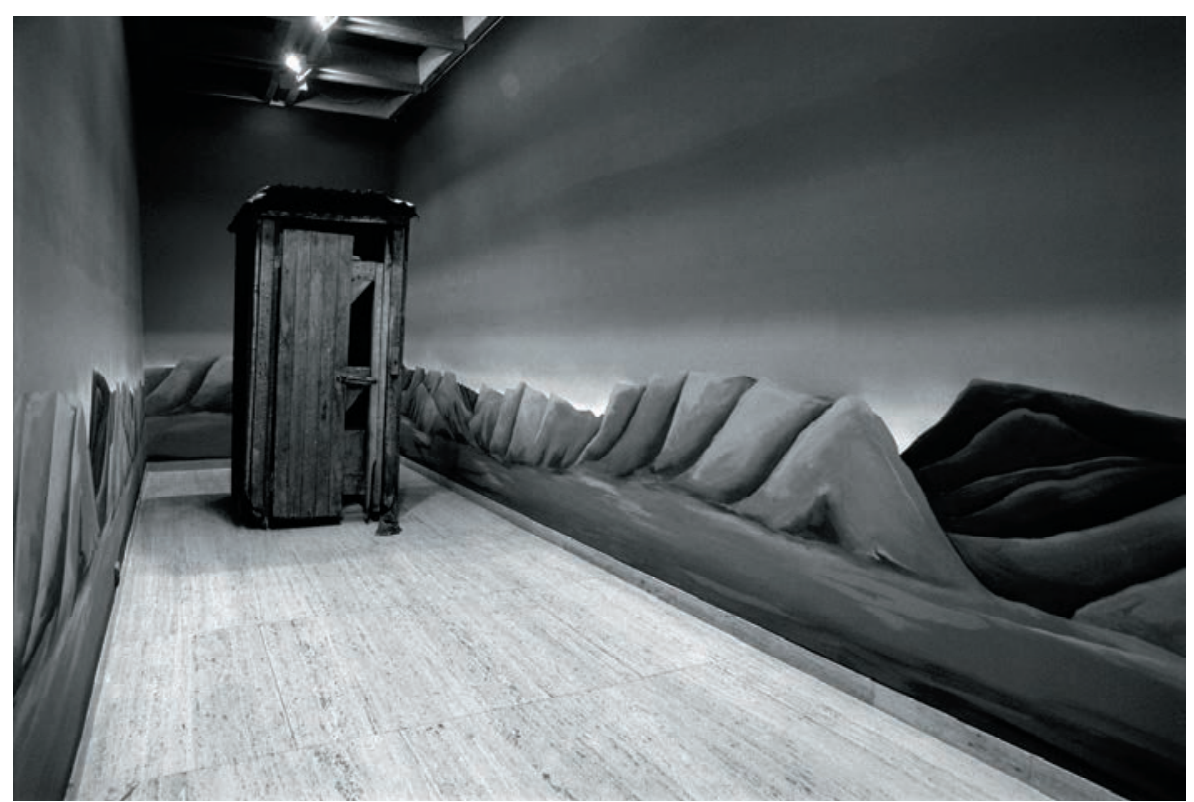

Figure I: Daniel Malone, A Long Drop To Nationhood, 2004, Readymade Kauri wood outhouse, wall mural, video with sound, export/import documentation, Dimensions variable. Photo Jenni Carter.

I. According to Tony Bond (2004), Malone talked in the catalogue "about the need for us, in Australia, to recoup our Aboriginality if you like. To acknowledge, in fact, that this is an indigenous country and not a colony." Malone, in fact, used excerpts from Germaine Greer's "Whitefella Jump Up: The Shortest Way to Nationhood" in the text of his catalogue entry rather than making his own artist's statement.

2. Thus, curator Isabel Carlos (2004) wrote in the catalogue: "The 'emotional' in Western societies has been connoted, almost to the point of cliché, with the south" (24). "In a conventional dichotomy we would say that the south is the body and the north the mind but, believing this to be a false dichotomy, one of my aims was to bring together artworks that create a total physical and psychological experience" (25). 
3. Interpreting the installation as an equation of colonisation with defecation, Nova Paul commented: "Malone identifies the long drop as belonging to both an Australian and Aotearoa/NZ architectural vernacular ... ingrained as part of our cultural identity; backward, funny and awkwardly displaced. It is this figure of the long drop that is activated in Malone's installation that addresses colonisation and sovereignty" (Paul, 2004).

4. Anaura Bay is located in Poverty Bay: http://southseas.nla. gov.au/journals/maps/17691029. html.

5. Similarly, a delegation protested in the seventeenth century at Troyes, when the mayor tried to close the rue de Bois, a public latrine: "Messieurs, our fathers have shit there, we shit there, and our children will shit there" (in Guerrand, 1997: 17). In 1894, a law concerning hygienic improvement in Paris "met with strong hostility from landlords, for once united in opposition to this collectivist and tyrannical infringement of their rights" (Perrot, 1990: 372).

6. Elias emphasised that, while the civilising process in Europe had no zero point, new codes became visible in these texts. They were a response to an increased population at the courts, and later in the cities. Not only did this new situation require different hygienic conditions, people were also bound together by what Elias calls "lengthening chains of dependence".

7. See Freud (1930: 296), Nietzsche (1884b: s.59, s.179) and Klossowski (2000: 26-30, 44-46, 257). Toilets are, from the beginning, tied up with the "traumatic excess" they cater for- "according to Lacan, one of the features which distinguishes man from animals is precisely that with humans the disposal of shit becomes a problem" (Žižek, 1997: 5).
In Malone's work mind and body, North and South, and settler culture and indigenous culture congeal "in the form of a dunny" (Biennale of Sydney Volume 1: Cake, 2004). ${ }^{3}$ But how much are perceptions of the dunny as an icon for 'Down Under' based on facts, and how much are they an investment in conventional notions of top and bottom, centre and periphery? After all, the privy was a common feature in Europe at the time of colonisation, often paired with appalling hygienic conditions. In contrast, one of Cook's crew noted at Anaura Bay, in October 1769, that "every house, or every little cluster of three or four houses, was furnished with a privy, so that the ground was every where clean. The offals of their food, and other litter, were also piled up in regular dunghills ..." (Hawkesworth, 1773: 312). ${ }^{4}$ Hawkesworth compared this favourably with conditions in the capital of a European nation, Madrid, where privies were rare until 1760. Prior to that, it was "universal practice to throw the ordure out of the windows, during the night, into the street, where numbers of men were employed to remove it, with shovels" (313). This appeared to contemporaries so normal that a Royal proclamation ordering proprietors to "build a privy", and announcing the construction of "sinks, drains, and common-sewers ... at the public expence [sic]" was seen "as an infringement of the common rights of mankind" and met with great resentment (313). ${ }^{5}$ The situation in the British capital was hardly better: the River Thames served as the sewer for a population of two million in 1830. In Manchester's Parliament Street, "one single privy" served "three hundred and eighty persons" in 1851, and "in Parliament Passage ... thirty thickly populated houses"' (Engels, 1845).

So where do notions of the North as mind and South as body originate? How can they be so persistent, despite contrary facts, that Malone and others see the need to engage with them and meet resonance in the audience?

\section{Civilisation: A long process of separation}

Between the eighteenth and the twenty-first century, according to Norbert Elias, a process that had been underway in Europe for some time reached a new stage. In The Process of Civilization (1939), Elias traces in historical documents a long-term development in European courts and cities. Over the course of this development, however, people eventually came to think of their civilisation no longer as a process but as a universal standard. Long sections of Elias' investigations are concerned with sixteenth century humanist texts, in which an unprecedented plethora of rules and regulations concerning the "natural functions" emerges. ${ }^{6}$ Much greater control of affects and impulses was called for, and this changed people's relationships with their own bodies and those of others.

Elias was theoretically informed by Sigmund Freud's ideas in Civilization and its Discontents (1930), in which civilisation appears as a burden that must be borne so as to avoid worse evils. Freud, in turn, owed much to Friedrich Nietzsche's thought, who once wrote that the difference between animals and humans depended on the latter's development of a plenitude of conflicting drives and impulses. Their synthesis, precisely, makes humans the masters of the earth. Nietzsche regarded the cerebral organ, just like the rest of the body, as the product of a confrontation of fortuitous impulses-each of which "would have been only too glad to look upon itself as the ultimate end of existence and the legitimate LORD over all the 
other impulses" (Nietzsche, 1886: s. 6). The intellect as an apparatus for selfregulation (Nietzsche, 1884a: s. 179), however, strives to sustain its position at the 'highest' extremity: high and low come to mean more than spatial positions (Klossowski, 2000: 26). Hierarchies of top and bottom secure the mastery of conflicting impulses. ${ }^{7}$

If Nietzsche prefigured some of Freud's insights into the relationship between impulses (or drives) and intellect (or ego), Elias historicized them by tracing the construction of selfhood since the fifteenth century in European courts. ${ }^{8}$ He observed how "pleasure-promising drives and ... socially generated feelings of shame and repugnance, come to battle within the self" (Elias, 1939: 160). Analogous to Freud's superego, "the social code of conduct so imprints itself ... on human beings that it becomes a constituent element of their selves". This leads to a "pronounced division in the 'ego' or consciousness" as a "characteristic of people in our phase of civilization" that "corresponds to the specific split in the behaviour which civilized society demands of its members" and "matches the degree of regulation and restraint imposed on the expression of drives and impulses" (160).

However, whereas Nietzsche still used metaphors of body and intellect almost interchangeably, ${ }^{9}$ Elias already took their division almost for granted. Further, the ego, in his thinking, not only mediates between conflicting impulses but also between impulses and the social commands of an era: ${ }^{10}$ changing social imperatives can advance the frontiers of shame and render previously inconsequential impulses intolerable. ${ }^{11}$ Thus "Changes in Attitudes Towards the Natural Functions" become apparent in humanist books on manners from the sixteenth to the eighteenth century. In 1530, Erasmus thought it necessary to point out that it "is impolite to greet someone who is urinating or defecating" (De civilitate morum puerilium in Elias, 1939: 110) and Della Casa repeated in 1558 that it "does not befit a modest, honourable man to prepare to relieve nature in the presence of other people" (110). Neither should one, "when coming across something disgusting in the sheet, as sometimes happens, ... turn at once to one's companion and point it out to him. It is far less proper to hold out the stinking thing for the other to smell ... when it would be better to say, "Because it stinks do not smell it'" (Della Casa 1558 in Elias, 1939: 111).

These are new injunctions, which speak of a lowered shame threshold. On the other hand, details are still discussed in the texts that will soon be passed over in silence. ${ }^{12}$ Interestingly, shame was associated not with guilt feelings, but with fear of exposure to those more powerful: certain things "are not done", as Della Casa observes elsewhere, "except among people before one is not ashamed" (117). ${ }^{13}$ Superiors produced shame in their inferiors by imposing on them stricter controls of impulses and emotions. Conversely, the "sovereign holding court on his pierced chair" was a privileged sight in French absolutist society. His subjects "bow[ed] and kneel[ed] in pursuit of a royal turd" (Laporte, 2000: 12).$^{14}$ A little more than two centuries later, Freud and his contemporaries were "astonished to learn of the objectionable smell which emanated from the Roi Soleil" (Freud, 1930: 281). Dirtiness now seemed "incompatible with civilisation" (281). Would Freud have been aware of the relative standards of cleanliness in European metropoles and those, for example, at Anaura Bay in 1769? ${ }^{15}$

The association of civilisation and toilet hygiene as we know it in the West made the toilet "a critical link between order and disorder" (Pathak,
8. The ego is, in Elias' account, the result of a slow process dividing people's lives into public and private. In this process, social pressures to restrain impulses were reproduced in individuals as self-controls, so completely that they continue even when alone (Elias, 1939: 160).

9. Experiences, for instance, are digested-like meals. If one cannot get over an experience, "this kind of indigestion is just as much a physiological matter as the other one-and in many cases, in fact, only one of the consequences of that other one" (Nietzsche, I887: s. 16). His awareness of bodily existence and his leaning to the irrational were (despite contradictory statements) out of step with the pace of the civilising processes of his time.

10. The latter change: in ancient Rome, for example, bronze or silver urine pots were part of the furnishings of dining rooms, brought out by slaves upon request during a dinner-presumably so that eating and conversation could continue (Guerrand, 1997: 14). And in Paris at the middle of the seventeenth century, it was still possible for a young gentleman to urinate while holding the hand of a noble lady and simply to apologise: "Excuse me Madam, if I have you kept waiting a little that is because I had so much urine in my body and it caused great inconvenience" (30).

\section{See Freud (1919: 24I).}

12. Elias demonstrates this with a comparison of two editions of La Salle's Les Règles de la bienséance et de la civilité chretienne (1729 and 1774). The earlier edition already surpasses Erasmus' text in its demands that all natural functions should be removed from the view of others (indicating that people actually did not conform with these rules at the time). While pronouncing that it is impolite to talk about them, the text still 
calls them by their names in detail. In the later edition, all these detailed references are dropped and they are 'passed over in silence'.

13. Some things that a "great lord" might do before "one of his servants or in the presence of a friend of lower rank" would not be a sign of arrogance "but rather a particular affection and friendship" (II7).

14. Given the possibility that the baring of one's private parts in front of an inferior can be a friendly gesture, the "men..., women, girls, boys, abbeys, Swiss Guards" passing by the houses next to the forest at Fontainbleau in 1694 may have felt honoured to watch Madame la Duchesse d'Orleans doing her business. She herself felt inconvenienced and wrote to the Electress of Hanover: "You are indeed fortunate to shit whenever you may please and to do so to your heart's content! ... We are not so lucky here. I have to hold on to my turd until evening: the houses next to the forest are not equipped with facilities. I have the misfortune ... of having to shit outside, which gravely perturbs me because I like to shit at my ease with my ass fully bared" (quoted in Laporte, 2000: 4, II).

15. Would it have been difficult for him to imagine that "savages" not so long ago were ahead of Madrid, Paris, or London in their separation of food and filth-without, for that matter, necessarily effecting the same psychological separations that accompanied European toilet training?

\section{See Vigarello (1988: 146).}

17. See note 5. In 1539, François, King of France, passed an edict that privatised his subjects' waste production. They were henceforth forbidden to toss out into the streets and squares "refuse, offals, or putrefactions, as well as all waters whatever their nature" and had

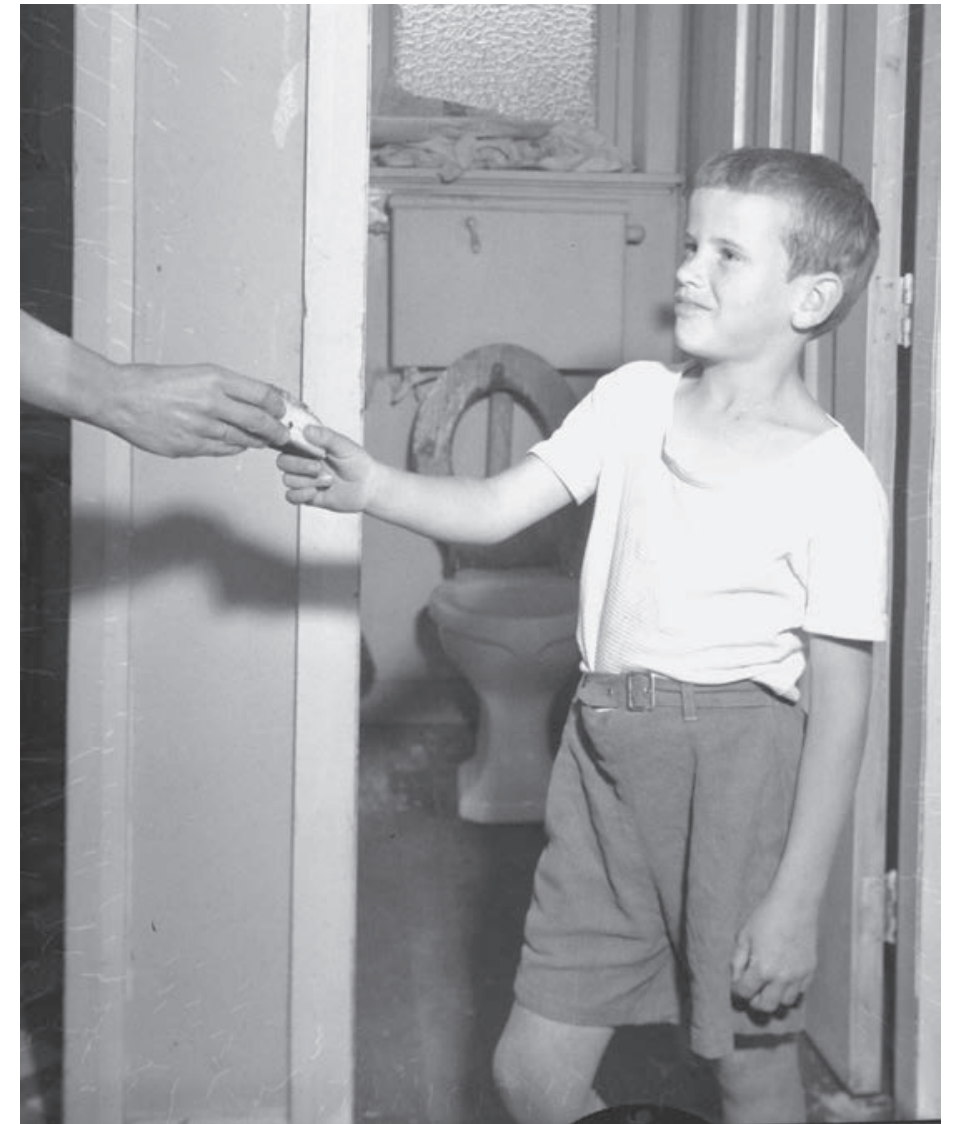

Figure 2: A boy being given soap to wash his hands after going to the toilet. Photo Auckland City Council, 1959-1960.

1995). The bathroom similarly featured, in a 1917 article "Bathrooms and Civilization", as "an index to civilization ... And in no line of building has there been so great progress in recent years as in bathroom civilization" (February issue of House and Garden, quoted in Lahiji \& Friedman, 1997: 81). It institutionalised the control of impulses and moulded individuals and groups further towards an ideal of civilisation.

Over the course of this development, demarcations between inside and outside were constantly reproduced: for example, the restraint of impulses was more and more exercised by European subjects themselves, rather than imposed from outside, as they adapted to the requirements of increasingly complex societies with lengthened chains of social interdependence. Similarly, the separation from excrement-initially managed through sheer distance-was re-integrated into the house once suitable hygienic technologies were developed. This shift meant simultaneously a further privatisation of bodily functions. Finally, the hygienist discourse accompanying those technical developments simultaneously applied to single bodies, groups and the larger social body. ${ }^{16}$ Certain groups of people were constructed as unhealthy for the social body and removed from the centre just like excrement; and, in many cases, by the same means: water. Let's look at the last two aspects now, in turn. 


\section{The State and the Sewer}

The history of European cities reflects a protracted struggle over waste management. For a long time, any number of enactments "could not prevent people from defecating in the open". ${ }^{17}$ But in the nineteenth century, techniques based on the reticulation of water and excrement became a matter of concern for a healthy, albeit invisible public body in the care of the state. At an international congress of hygiene, held in Brussels in 1852, English hygienist F.O. Ward described a system based on the "constant circulation of water" in and out of the city (in Gille, 1986: 235). This system linked the city with the country through "a vast tubular structure that has two divisions; ... each of these divisions is made up of two distinct subdivisions: an afferent, or arterial system: and an efferent, or venous system" (236). He concluded that "it is a matter of just pride for us that our country" should have conceived of "this purely analogous discovery-circulation in the social body" (237).

English hygienists were initially in the forefront of this development but, soon, other European nations entered the body works competition. ${ }^{18}$ It is in the context of intensifying national rivalry in Europe that Adolf Loos' 1898 essay "Plumbers" makes sense:

Increasing water usage is one of the most pressing tasks of a culture. May our Viennese plumbers therefore do their jobs as fully and completely as possible in order to lead us to this great goalthe attainment of a cultural level equal to the other countries of the civilized Western world. For otherwise something very unpleasant, something very shameful could take place. (Loos, 1898: 19) ${ }^{19}$

On the upper levels of London society, a "compulsory cleanliness" made itself felt towards the end of the nineteenth century and the "wash-out closet" (elsewhere known as the 'English basin') became popular (Laporte, 2000: 61, 59). A range of products catered for "new notions of cleanliness, order, and, by extension, beauty", at least for the upper classes, and an "architectural abandon" turned some 'public' conveniences into commemorative shrines, "chapels to waste" (60), where "civilized man deposited offerings and prayers to ward off the ... awareness of his primordial origins" (61). To control matter in the combat of the impulses, architectural force of form was enlisted. Whereas matter "presses down and wants to spread out formlessly on the ground" (Wölfflin, 1886: 159), form can provide an upright condition resisting any residual forces of a primordial condition to be forgotten or overcome. ${ }^{20}$

Water closets and sewers were part of a characteristic process of segregation by which a whole range of body functions was removed from social life and displaced behind the scenes. With the availability of a technical apparatus allowing for the quick separation of body and excrement, excretion could once again take place within the house or apartment. ${ }^{21}$ Since the end of the sixteenth century, the prevailing attitude in architectural treatises had been to remove 'the place' as far as possible from the actual places of dwelling. ${ }^{22}$ When Julien Guadet, influential teacher of architects at the École des Beaux-Arts wrote in 1901 that "as far as the toilets are concerned, we place them without any fear ... into the midst of the apartment" (1901: "to delay and retain any and all stagnant and sullied waters and urins [sic] inside the confines of [their] homes" (quoted in Laporte, 2000: 4, II). In keeping with rules that applied different standards to superiors and inferiors, however, waste in the King's castles continued to be disposed of outside.

18. Haussmann regarded the Parisian sewers in 1854 as "the organs of the metropolis" which "function like those of the human body" (quoted in Gandy, 1998). See also Gille (1986: 228).

19. The "shameful" and "unpleasant" was the possibility that Japan could "attain Germanic culture before Austria" (19).

20. As Ross Jenner outlines in his contribution to this issue, several architectural theorists have seen parallels between the flow of forces of bodily impulses and those in the built environment. Heinrich Wölfflin considered the "opposition between matter and force of form" the "principal theme of architecture". "We assume that in everything there is a will that struggles to become form and has to overcome the resistance of a formless matter" (Wölfflin, 1886: 159). Will, or the force of form, is what "holds us upright and prevents a formless collapse" (I59). There is more than a faint overlap with Nietzsche's thought here. Henry Staten (1990: 166) writes of Nietzsche's concern with the conflict between force and form that the "endless dispersal of the substance of humanity can only be brought to a halt by and aim upward, an aim at a goal". Staten goes on to remark that "wherever there is the desire for meaning and the search for something more durable than the pointless pouring-fourth of life, there will usually also be the distinction between the human and the animal, fear of the female who disperses one's substance, and loathing of the corruption of the body" (167). 
21. While this apparatus does not explain the "advance in the frontiers of shame and the threshold of repugnance", once in place, it consolidates and constantly reproduces the new standards and their dissemination (Elias, 1939: 99, II8-9).

22. See Guerrand (1997: 26, 39). In I883, it was still common in Parisian apartment blocks or tenements to find one privy for twenty five persons, placed somewhere in the entrance area or courtyard (137). Only legislation passed in 1894 made it compulsory for new buildings to allow for internal toilets. This did not necessarily mean their placement in the apartments themselves, and-if so-they were usually tucked away bordering onto the kitchen and the servants' realm.

23. There is a structural parallel between the segregation of 'the place' from normal life and Elias' notion of the dampening of affects, on the one hand, and, on the other, the integration of the WC into the middle of the house and a relaxation of the control of affects, following a sufficient moulding of individual psyches. See "Decivilizing and informalization processes" in van Krieken (n.d.). An interesting extreme case of moulding of affects is that of prisoners in Jeremy Bentham's panopticon cells: "A slight screen, which the prisoner might occasionally interpose, may perhaps not be thought superfluous. This, while it answers the purpose of decency, might be so adjusted as to prevent his concealing from the eye of the inspector any forbidden enterprise" (http://cartome.org/panopticonl.htm).

24. Slavoj Žižek finds an analogy between German, French, or American toilet constructions and national political characteristics: "German reflective thoroughness, French revolutionary hastiness, English moderate utilitarian pragmatism" are reflect-
62), he clearly announced a new trend in architectural design that set itself in opposition to common practice. Much of the discussion at the time was concerned with health and hygiene-but these were not the only factors. ${ }^{23}$

Thomas Crapper's flush toilet, according to a 1993 Chicago Tribune article, changed

the course of history by allowing society to live with itself. It is more than valves and arms and floats that hiss and gurgle; the flush toilet is the very symbol of modern civilization. ... Life without the water closet is, for most of us, a horror beyond imagination, so unspeakable and unacceptable that we cannot conjure up the prospect. (Ecenbarger, 1993) ${ }^{24}$

According to another non-academic source, Queen Victoria's "porcelain throne" represented an attitude that may well have "seemed more 'dignified'-more suited to aristocrats than the method used by the natives in the colonies" (Health Benefits of the Natural Squatting Position, 2001). Is it not surprising how civilisation, since the nineteenth century, has become a maxim for dominant European views of national achievements? Does it not stand, even today, for stable and consummate standards, which place 'civilised' nations far ahead of those who have supposedly not yet reached their level of progress? ${ }^{25}$

\section{Imperial reticulations}

Nineteenth century fears of social division and the contagion of poverty-related diseases eventually led to a wholesale purging of dangerous elements-be they matter or humans. Points of intensive crowding, such as hospitals, barracks, prisons and workers' housing, were to be "moved to the edge of the city, where conditions of isolation and ventilation would guarantee both their security and that of the city" (Fonssagrives quoted in Gille, 1986: 229). With that, the hygienists' programme spilled over-or returned to-issues not only of architecture, but also of politics.

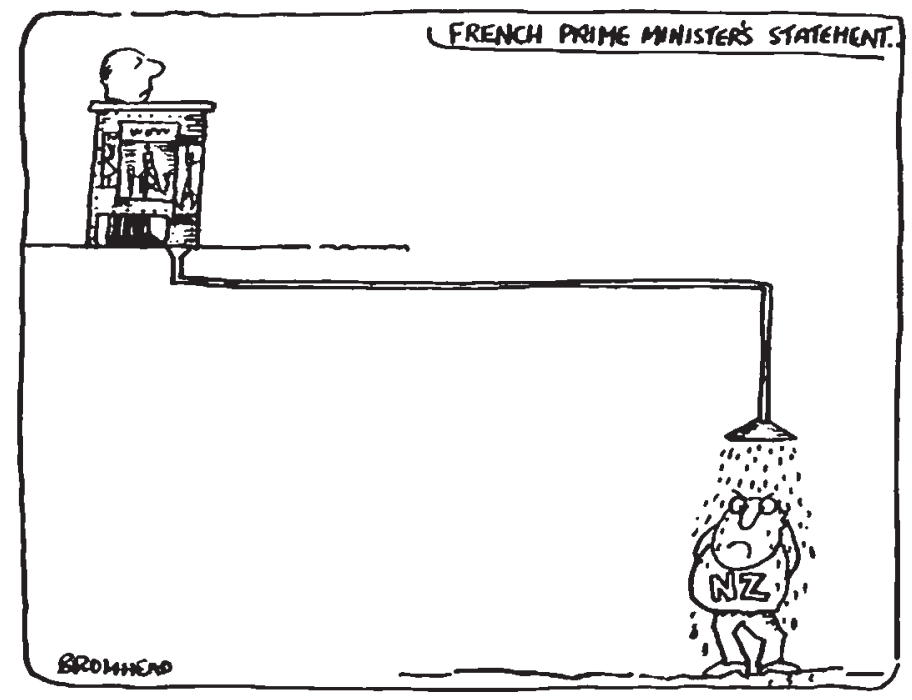

Figure 3: Peter Bromhead, French Prime Minister's statement. 29 August 1985. 
Waste management in the context of colonisation became the imperial reticulation of a poor or criminal population beyond national borders. Following the American colonies' embargo on convicts, the colonisation of Botany Bay was to ensure the ongoing flushing away of criminals (and the poor). However, ex-convicts-or escaped convicts-perhaps unexpectedly also ended up in the New Zealand colony, which, in Edward Gibbon Wakefield's scheme, served as another, different and more wistful variation of a 'safety-valve' for overpopulation, endemic unemployment and poverty in England.

Already Elias observes, it was "not a little characteristic of the structure of Western society that the watchword of its colonizing movement is 'civilization"' (1939: 509), and Robert van Krieken (1997) argues that any "self-conscious attempts to bring about 'civilization', have revolved around essentially violent policies and practices". Barbarism and civilization are thus "part of the same analytical problem" rather than successive stages of development (1997).

In the colonies, according to Laporte, civilisation is "the purview of the conqueror. The barbarian craps where he pleases; the conqueror emblazons his trails with a primordial prohibition: 'No shitting allowed'" (2000: 57). The coloniser, according to Professor McHugh in Ulysses, brings with him to new shores "only his cloacal obsession": "It is meet to be here. Let us construct a water closet" (Joyce, 1922). Cloacal obsession in the nineteenth century was articulated through progressivist vocabularies of hygiene and toilet technologies. ${ }^{26}$

The water closet might have represented an achievement in nineteenth century Europe, with its particular problems of over-crowding. But a peculiar myopia excluded from perception historical and geographical particularities such as the vast difference between the metropoles and the hinterland in Europe, or earlier observations of barbarians and civilised such as Hawkesworth's notes about hygienic conditions in Anaura Bay in 1769. These lapses of historical and geographical awareness supported a particular ideological system by which one type of toilet comes to mean something different from another, in peculiar ways. The perception of the

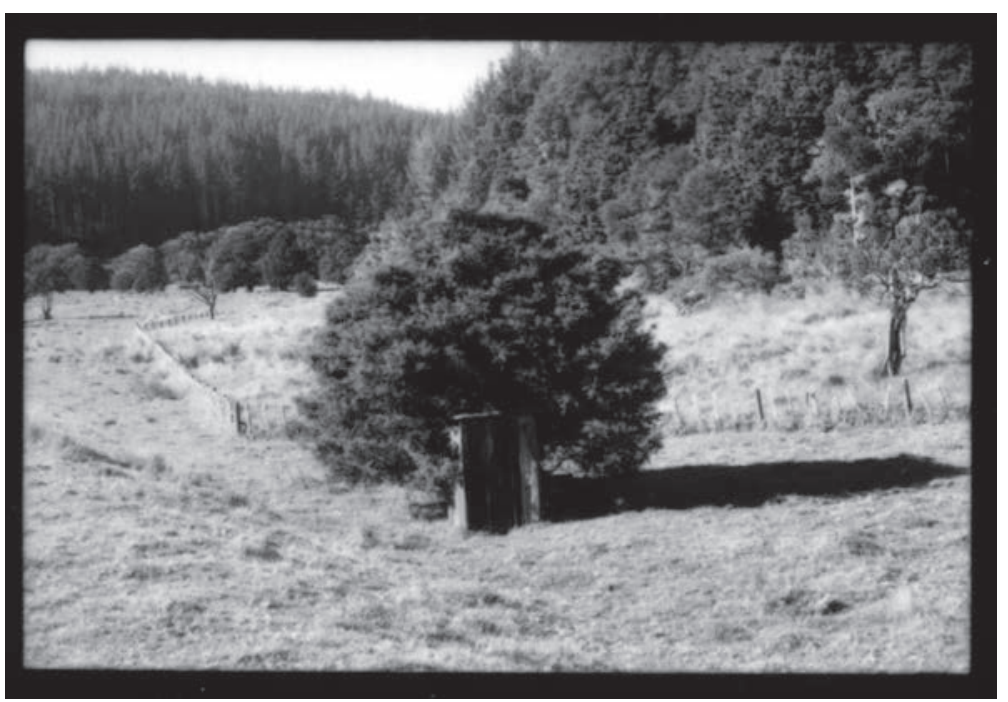

Figure 4: Daniel Malone, In Situ, Opouteke, Northland, Aotearoa/New Zealand, (Partially Covered Outhouse), 2004, Black and white photograph. ed in "ambiguous contemplative fascination; the hasty attempt to get rid of the unpleasant excess as fast as possible; pragmatic approach to treat the excess as an ordinary object to be disposed of in an appropriate way" (1997: 5).

25. For long periods, civilization in Europe had been an ideal rather than a reality, but by the second half of the nineteenth century it had become a maxim for dominant European views. As a goal, it shaped the process of interior restructuring that accompanied industrialisation, the rivalry of nation states, and expansionary and imperialist politics. The reference to nationhood in Malone's installation is interesting in this context.

25. Such progressivist vocabularies may have even taken in Norbert Elias, who at times-despite his continuous discomfort with the notion of civilisation as achievement or standard-lapsed into his own brand of progressivism. See Elias (1995).

26. The compulsive need to eradicate traces of the 'olfactory animal' by immersing shit in floods of water, the spite civilisation has for odour, and the ferocity with which it will oust it- "this ferocity reaches its peak when imperialism punishes color" (Laporte, 2000: 83). Brantlinger observed that the Victorian middle classes not only displaced "their own 'savage' impulses onto Africans". They suffered from a fear of "backsliding" which was activated both by the protelarian mob and the colonial barbarians (1985: 196). If the mob uses a floor torn open as a privy, and if the natives shit on the ground, then white civilization must be identified with hygienist ideals of flushing toilets and well circulating sewers. 
long-drop as an icon of the New Zealand or Australian vernacular, or of the lavatory as one of civilizing achievement, is based on imaginary investment rather than facts. The long-drop's appearance in the Sydney Biennale, revisiting the 'forgotten' world of dunnies and night carts, may be read as a return of what was repressed or eliminated in the process of civilisation. Alternatively, it may index an intrinsic part of a European barbarism that was always folded into civilisation.

Separations of the metropolis from its excess population, of settlers and natives, and between body and excrement may have been parallel and interconnecting processes. They are all concerned with literal or metaphorical top/bottom relationships. When Malone calls his installation A Long Drop to Nationhood, the title implies not only the physical movement of matter (down, as opposed to mind: up) but also an implied loss of status, from centre to colon-y. Implicit is still an unspoken assumption that people at

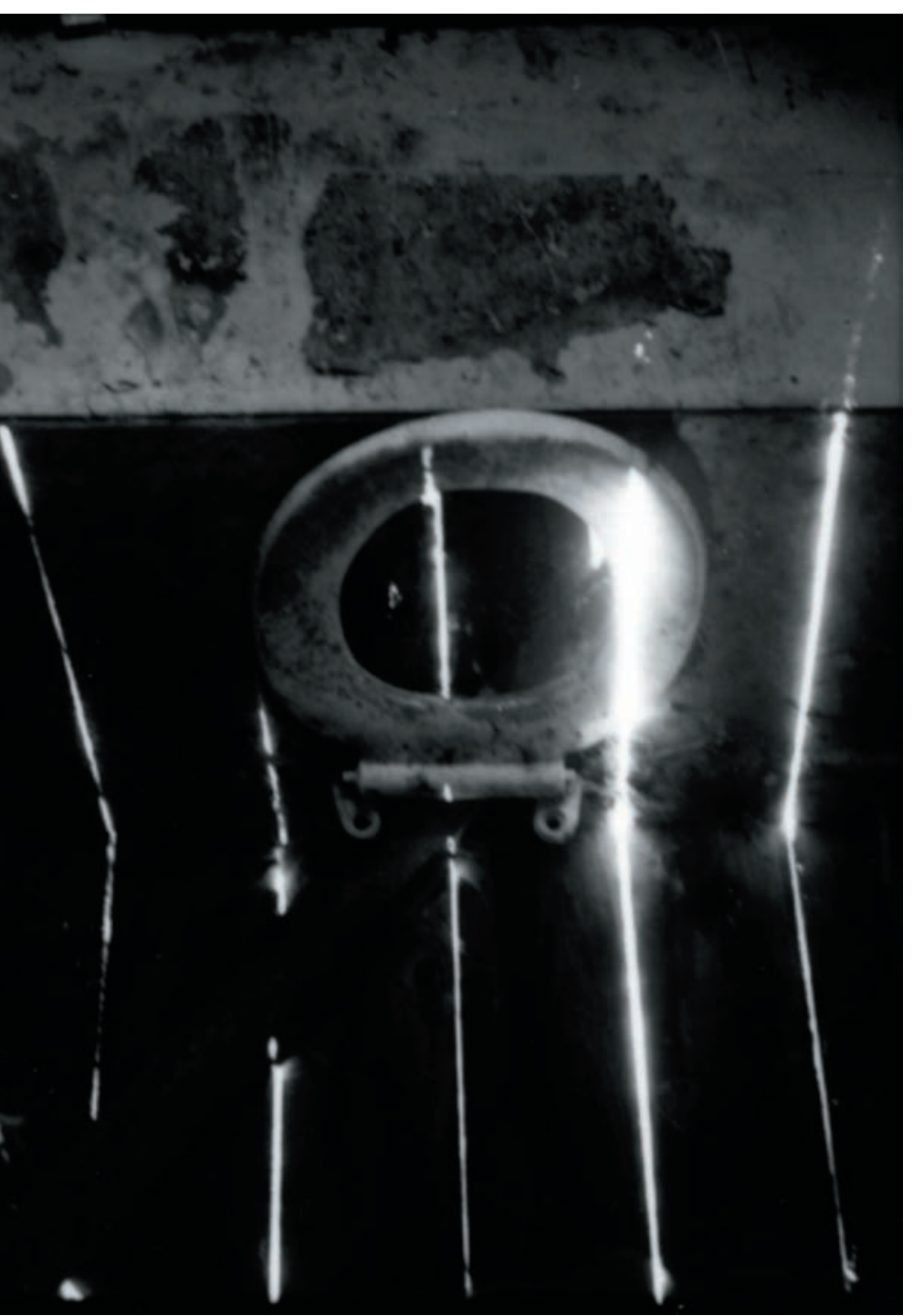

Figure 5: Daniel Malone, In Situ, Opouteke, Northland, Aotearoa/New Zealand, (Toilet Seat), 2004, Black and white photograph. 
the centre have not only decided the combat of the impulses, but also have a right by virtue of their (our?) higher standard of civilisation to make others do as they (we?) do. ${ }^{27}$

What Malone's metaphor implies is that Australia and New Zealand share a colonial history, and that a long-drop is the makeshift, unsophisticated convenience attached to that condition. Once accepted, the metaphor extends and gets mixed with the brutality and arrogance of colonial politics in both countries.

Much of what happened at Okahu Bay (Orakei) in the 1950s, ${ }^{28}$ for example, was justified by references to hygiene and health: Ngati Whatua, in their struggle to maintain their rights of occupancy at Okahu Bay, found their efforts over decades of court procedures blighted by health concerns. Thus, a 1935 sanitary report held "swampy conditions and inadequate drainage" against the continued existence of the Okahu Bay papakainga (habitation).

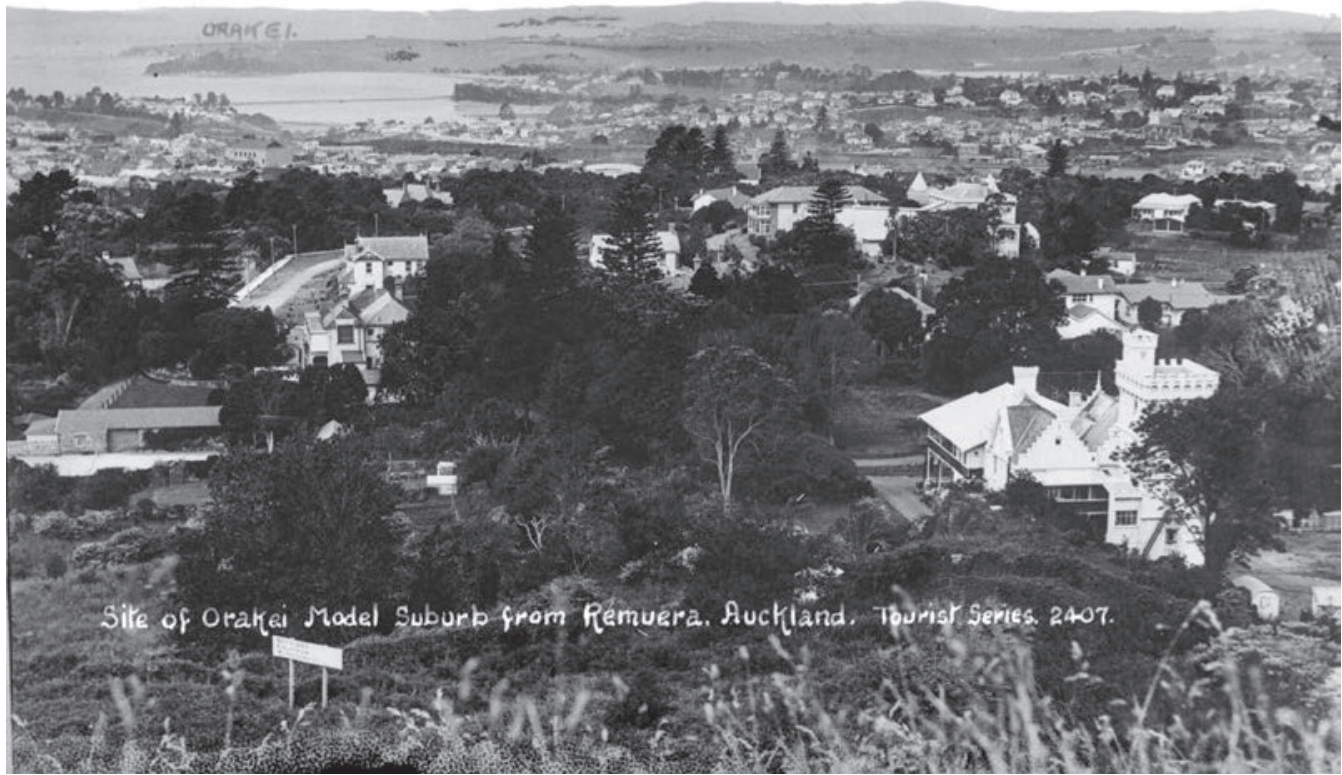

Figure 6: Frederick G. Radcliffe, Looking north east from Mount Hobson towards Orakei showing a real estate sign in foreground, "Sections Finest View Winstone Ltd".
27. Okahu Bay is situated in what is now a central Auckland region. About its history, see Waitangi Tribunal report (1986), particularly in this context: Chapter 7: "Cleaning Up 1930-1952".

28. In 1952 "those left had to be burnt out and physically carried from their homes. It seemed necessary that that should not be delayed. Her Majesty Queen Elizabeth II was to visit Auckland in the coming summer 19521953." Her route of arrival was at the time expected to pass the "unsightly Orakei shacks"-a prospect the council could not countenance.

29. The outfall was located at the head of Okahu Bay. From 1914 “Auckland's crude sewage was discharged to the shellfish beds of Ngati Whatua, opposite their ancestral village. There could have been no greater insult to a Maori tribe even if one were intended" (Waitangi Tribunal, 1986). 


\section{References}

1954: Looking back 50 years. (2004). Retrieved 13 March, 2005, from http://events.filmarchive. org.nz/event.php?eventInstanceID $=454 \&$ eventID $=124$

Biennale of Sydney volume 1: Cake. (2004). Retrieved 13 February, 2005, from http://artlife. blogspot.com/2004_06_01_artlife_archive.html

Bond, T. (2004). DANIEL MALONE : A long drop to nationhood - 2004. Friday, 19 November 2004 - Visit the Biennale at the Art Gallery of New South Wales. Retrieved 15 January, 2005, from http://abcasiapacific.com/nexus/gallery/s1234056.htm

Brantlinger, P. (1985). Victorians and Africans. Critical Inquiry, 12 (Autumn), 166-203.

Carlos, I. (2004). On reason and emotion. In On reason and emotion: Biennale of Sydney 2004 (24-27). Sydney: Biennale of Sydney.

Daniel Malone. (2004). Retrieved 12 September, 2004, from http://www.biennaleofsydney. com.au/Biennale2004/2004/artists/Daniel\%20Malone.html

Ecenbarger, W. (1993). Flushed with success: Never have so many owed so much to one almostforgotten inventor. Retrieved 12 August, 2004, from http://ce.ecn.purdue.edu/ piwc/w3-history/crapper/crapper-ecenbarger.html

Elias, N. (1939). The civilizing process: Sociogenetic and psychogenetic investigations (E. Jephcott, Trans. Revised Edition, Eric Dunning, Johan Goudsblom and Stephen Menell Eds.). Oxford: Basil Blackwell.

Elias, N. (1995). Technization and civilization. Theory, culture and society, 12 (3), 7-42.

Engels, F. (1845). The condition of the working class in England. Retrieved 4 Sept, 2004, from http://www.marxists.org/archive/marx/works/1845/condition-working-class/index.htm

Freud, S. (1919). The uncanny (J. Strachey, Trans.). In J. Strachey (Ed.), The standard edition of the complete psychological works of Sigmund Freud (Vol. 17, 219-256). London: The Hogarth Press.

Freud, S. (1930). Civilization and its discontents. In A. Dickson (Ed.), Civilization, society and religion (Vol. 12, 251-340). Harmondsworth: Penguin.

Gandy, M. (1998). The Paris sewers and the rationalization of urban space. Retrieved 12 September, 2004, from http://www.strath.ac.uk/Departments/gs/pdf/Gandy.pdf

Gille, D. (1986). Maceration and purification. Zone, 1/2, 227-281.

Guadet, J. (1901). Éléments et théorie de l'architecture: Cours professé a L'École nationale et spéciale des beaux-arts. Paris: Librarie de la construction moderne.

Guerrand, R.-H. (1997). Les lieux: Histoire des commodités. Paris: Editions La Découverte.

Hawkesworth, J. (1773). CHAP. II. A description of Poverty Bay, and the face of the adjacent country. The range from thence to Cape Turnagain, and back to Tolaga; with some account of the people and the country, and several incidents that happened on that part of the coast. Retrieved 12 January, 2005, from http://nla.gov.au/nla.cs-ss-jrnl-hv23-title

Health benefits of the natural squatting position. (2001). Retrieved 14 July, 2004, from http:// www.naturesplatform.com/health_benefits

Žižek, S. (1997). The plague of fantasies. London: Verso.

Joyce, J. (1922). Ulysses. Retrieved 15 May, 2005, from http://www.web-books.com/Classics/ Fiction/Other/Joyce_Ulysses/Ulysses_07_4.htm

Klossowski, P. (2000). Nietzsche and the vicious circle (D. W. Smith, Trans.). London: Athlone.

Lahiji, N., \& Friedman, D. S. (Eds.). (1997). Plumbing: Sounding modern architecture. New York: Princeton Architectural Press.

Laporte, D. (2000). History of shit (N. Benabid \& R. el-Khoury, Trans.). Cambridge (Mass.): MIT Press.

Loos, A. (1898). Plumbers. In N. Lahiji \& D. S. Friedman (Eds.), Plumbing: Sounding modern architecture (15-19). New York: Princeton Architectural Press. 
Nietzsche, F. (1884a). Nachlass, 25. Die ewige Wiederkunft. Eine Wahrsagung. Spring 1884. Retrieved 21 January, 2005, from http://thenietzschechannel.fws1.com/nachd25a.htm

Nietzsche, F. (1884b). Nachlass, 27. Zarathustrasheft, Summer-Autumn 1884. Retrieved 1 February, 2005, from http://www.friedrichnietzsche.de/index.php?REM_sessid=a647735ab27 349514ec4b8c59809238d

Nietzsche, F. (1886, 2003). Beyond good and evil. Retrieved 6 June, 2004, from http://ftp.it.net. au/gutenberg/etext03/bygdv10.txt

Nietzsche, F. (1887). On the genealogy of morals. Retrieved 5 September, 2004, from http:// www.geocities.com/thenietzschechannel/

Pathak, B. (1995). International history of toilets. Retrieved 15 November, 2004, from http:// www.sulabhtoiletmuseum.org/pg02.htm

Paul, N. (2004). Dumping ground. Paper presented at the Interstices lecture series "Animal/ Impulse", Auckland, The University of Auckland/Auckland University of Technology.

Perrot, M. (Ed.). (1990). A history of private life IV: From the fires of revolution to the Great War. Cambridge (Mass.): Harvard University Press.

Staten, H. (1990). Nietzsche's voice. Ithaka: Cornell University Press.

van Krieken, R. (1997). The barbarism of civilization: Cultural genocide and the 'stolen generations' or Elias in the Antipodes. Paper presented at the Elias Centenary Conference, Amsterdam, 18-20 December, 1997. Retrieved 15 January, 2005, from http://www.usyd.edu. $\mathrm{au} / \mathrm{su} /$ social/elias/confpap/genocid2.html

van Krieken, R. (n.d.). Norbert Elias and process sociology. Retrieved 12 January, 2005, from http://www.usyd.edu.au/su/social/robert/papers/ritzer.htm

Vigarello, G. (1988). Concepts of cleanliness: Changing attitudes in France since the Middle Ages (J. Birell, Trans.). Cambridge: Cambridge University Press.

Waitangi Tribunal. (1986). Report of the Waitangi Tribunal on the Orakei claim (Wai 9). Retrieved 10 February, 2005, from http://www.waitangi-tribunal.govt.nz/reports/northislandnorth/wai9/toc.asp

Wei, L. (2004). South by southeast: The 14th Sydney Biennale avoided many of the excesses typical of international art festivals by showing fewer artists and newer, often specially commissioned works. Retrieved 18 September, 2004, from http://www.findarticles.com/p/articles/mi_ $\mathrm{m} 1248 /$ is_11_92/ai_n7637905/pg_2

Wölfflin, H. (1886). Prolegomena to a psychology of architecture. In H.F. Malgrave (Ed.), Empathy, form and space: Problems in German aesthetics, 1873-1893 (149-192). Santa Monica: The Getty Center of the History of Art and the Humanities. 